\title{
MENGEMBANGKAN SIKAP DAN PERILAKU ANAK USIA DINI MELALUI PENDIDIKAN BERBASIS KARAKTER
}

Edi Rohendi

\begin{abstract}
Abstrak
Pendidikan karakter merupakan upaya-upaya yang dirancang dan dilaksanakan secara sistematis untuk membantu peserta didik memahami nilainilai perilaku manusia yang berhubungan dengan Tuhan Yang Maha Esa, diri sendiri, sesama manusia, lingkungan. Kemudian nilai-nilai tersebut dapat terwujud dalam pikiran, sikap, perasaan, perkataan dan perbuatan. Sesuai dengan karakteristik anak usia dini, maka sifat-sifat materi pembelajaran adalah materi yang bersifat aplikatif, enjoyble, dan mudah ditiru. Dalam pengembangan sikap dan perilaku anak usia dini berbasis karakter, terdapat empat hal penting yang mesti diperhatikan ketika mereaktualisasikan pendidikan karakter, yakni melalui: (1) memberi pemahaman yang benar tentang pendidikan karakter, (2) pembiasaan, (3) contoh atau teladan, (4) pendidikan atau pembelajaran secara integral.
\end{abstract}

\section{Kata Kunci: Pendidikan Karakter, Anak Usia Dini, Sikap, Perilaku}

\section{A. Pendahuluan}

Pendidikan karakter adalah pendidikan untuk membentuk kepribadian seseorang yang salah satunya melalui pendidikan budi pekerti yang hasilnya dilihat dalam tindakan nyata seseorang yaitu tingkah laku yang baik, jujur dalam perkataan dan perbuatan, mempunyai tanggung jawab, sehingga terealisasi konfigurasi antara olah pikir, olah hati, olah rasa-karsa dan olah raga dalam kehidupan nyata . Budi pekerti dalam bahasa Arab disebut Khulk, disebut juga perangai tingkah laku, atau tabiat, watak, kesusilaan (kesadaran etik dan moral) yaitu kelakuan baik yang merupakan akibat dari setiap jiwa yang benar terhadap khalik-Nya dan terhadap sesame manusia (Ahmad Amin dalam Humaidi Tatapangarsa(1973).

Pendidikan karakter merupakan upaya-upaya yang dirancang dan dilaksanakan secara sistematis untuk membantu peserta didik memahami nilainilai perilaku manusia yang berhubungan dengan Tuhan Yang Maha Esa, diri sendiri, sesama manusia, lingkungan. Kemudian nilai-nilai tersebut dapat terwujud dalam pikiran, sikap, perasaan, perkataan dan perbuatan. Manusia 
dilahirkan dengan membawa dan memiliki potensi-potensi yang harus dikembangkan. Hakikat dasar pendidikan karakter adalah apa yang menjadi potensi manusia yang harus dikembangkan. Ini berarti juga pada diri manusia terdapat bibit potensi kebenaran dan kebaikan yang harus didorong melalui pendidikan Perlu diketahui bahwa pada dasarnya manusia sudah memiliki potensi. Potensi yang dibawa setiap anak adalah potensi kesucian. Sebagaimana tersebut dalamAl Quran surat Al Arof ayat 172: "Dan in gatlah, ketika tuhanmu mengeluarkan keturunaan anak -anak Adam dari sulbi mereka, dan Allah mengambilpersaksian terhadap jiwa mereka (seraya berfirman) "Bukankah Aku ini Tuhanmu”.Mereka menjawab, “Betul .Engkaulah Tuhan kami. Kami menjadi saksi”. Ini artinya sejak lahir anak sudah memiliki karakter baik yakni potensi bertauhid kepada Allah.

Pendidikan karakter merupakan misi utama para Nabi, seperti Muhammad Rasulullah sedari awal di utus ke dunia untuk menyempurnakan karakter (Akhlak). "saya diutus ke dunia ialah untuk menyempurnakan akhlak yang mulia”(liutammima makarimalakhlaq). Manifesto Muhammad Rasulullah ini mengindikasikan bahwa pembentukan karakter merupakan kebutuhan utama bagi tumbuhnya cara beragama yang dapat menciptakan peradaban.

\section{B. Urgensi Karakter}

Akhlak atau karakter sangatlah urgen bagi manusia. Urgensi karakter ini tidak saja dirasakan oleh manusia dalam kehidupan perseorangan tetapi juga dalam kehidupan berkeluarga dan bermasyarakat bahkan tidak kurang-kurangnya juga dirasakan dalam kehidupan berbangsa dan bernegara. Peranan Akhlak ini melebihi peranan ilmu pengetahuan. Karakter merupakan salah satu aspek kepribadian. Dilihat dari sudut pengertian, antara karakter dan akhlak tidak memiliki perbedaan yang signifikan. Keduanya didefinisikan sebagai suatu tindakan yang terjadi tanpa pemikiran lagi karena sudah tertanam dalam pikiran, dan keduanya sudah kebiasaan.

Ahmad Syauqi tokoh penyair Arab memperingatkan dalam syairnya yang artinya "Bangsa itu hanya bisa bertahan bilamana mereka masih memiliki 
karakter. Bila karakter telah lenyap dari mereka, mereka pun akan lenyap pula”.Humaidi Tatapangarsa(,1973)

Thomas Lickona yang disampaikan Ratna Megawangi dalam Aswandi (2010), mengungkapkan sepuluh tanda sebuah bangsa sedang menuju jurang kehancuran, yaitu :

1. Meningkatnya kekerasan di kalangan remaja

2. Penggunaan kata dan bahasa yang memburuk;

3. Pengaruh peer group yang kuat dalam tindak kekerasan

4. Meningkatnya perilaku merusak diri

5. Semakin kaburnya pedoman moral baik dan buruk

6. Menurunnya etos kerja

7. Semakin rendahnya rasa hormat kepada orang tua dan guru

8. Rendahnya rasa tanggung jawab individu dan negara

9. Membudayanya ketidakjujuran

10. Adanya rasa saling curiga dan kebencian di antara sesama

(Ratna Megawati, dalam Aswandi 2010)

Karakter yang baik lebih dari sekedar perbuatan, melainkan sebuah pilihan yang membawa kesuksesan. Ia bukan anugerah, melainkan dibangun sedikit demi sedikit dengan pikiran, perkataan, perbuatan, kebiasaan, keteladanan, keberanian, usaha keras, dan bahkan dibentuk dari kesulitan hidup.

Para pakar pendidikan dalam Aswandi (2010) mengelompokkan karakter ke dalam Sembilan (9) pilar, yakni :

1. Cinta Tuhan dan ciptaan-Nya;

2. Kemandirian dan tanggung jawab;

3. Kejujuran, amanah, dan bijaksana;

4. Hormat dan santun;

5. Dermawan, suka menolong dan gotong royong;

6. Percaya diri, kreatif, dan pekerja keras;

7. Kepemimpinan dan keadilan;

8. Baik dan rendah hati;

9. Toleransi, kedamaian dan kesatuan. 
Karakter bukan sesuatu yang tabu untuk diubah atau dibentuk. guru mampu melakukan pembentukan karakter melalui pendidikan. Karakter anak dapat dibentuk sehingga menjadi suatu kepribadian apakah melalui budi pekerti atau bentuk apa yang hasilnya akan terlihat dalam perilaku anak berupa tingkah laku yang baik, jujur, tanggung jawab, menghormati orang lain, kerja keras,menghormati guru, hidup tertib, disiplin, terkendali emosi dan bersikap atau berperilaku baik. Karakter adalah pengawalan untuk membangun kebiasaan agar mengetahui nilai-nilai kebenaran ,bisa mengembangkan kebenaran, dan terbiasa untuk melakukan kebenaran yang diyakininya. Kemendiknas Mohammad Nuh telah merancang “Grand Design” pembelajaran pendidikan karakter di sekolah. Acuannya telah ditetapkan kemendiknas adalah pengelompokan konfigurasi karakter, yakni olah hati, olah pikir, olah rasa-karsa dan olah raga.

\section{PENDIDIKAN BERBASIS KARAKTER PADA ANAK USIA DINI}

Sesuai dengan karakteristik anak usia dini, maka sifat-sifat materi pembelajaran adalah materi yang bersifat aplikatif, enjoyble, dan mudah ditiru. Dalam pengembangan sikap dan perilaku anak usia dini berbasis karakter, Aswandi dalam jurnal (2010) mengatakan, terdapat empat hal penting yang mesti diperhatikan ketika mereaktualisasikan pendidikan karakter, yakni melalui: (1) memberi pemahaman yang benar tentang pendidikan karakter, (2) pembiasaan, (3) contoh atau teladan, (4) pendidikan atau pembelajaran secara integral. Untuk lebih terperinci penulis akan membahasnya satu persatu.

\section{Memberi pemahaman}

Dalam pendidikan karakter yang pertama dipersiapkan oleh pendidik dalam hal ini seorang guru adalah bagaimana menanamkan pemahaman tentang karakter kepada anak didik, seperti dari grad design tadi apa-apa saja yang dikelompokkan kepada olah hati, olah pikir, olah rasa, dan olah raga., Seperti apa, bagaimana maksudnya , sangsi apa kalau tidak dilaksanakan dan sebagainya. Supaya tidak ada kesan bahwa pendidikan karakter sulit diterapkan di negeri ini, dan ketidakjelasan konseptual tentang pendidikan karakter yang kemudian berakibat pada kebijakan di tingkat lokal , maka perlu disampaikan konsep yang 
diajarkan. Dalam konsep mengajarkan ini guru memberikan kesempatan kepada peserta didik untuk mengajarkan apa yang dipahami siswa, apa yang pernah dialaminya dan bagaimana perasaannya berkenaan dengan konsep yang diajarkannya tentang sesuatu yang pernah dialami atau pernah teramati oleh peserta didik yaitu dengan contoh-contoh yang mereka alami. Materi-materi ini seyogyanya yang aplikatif bagi anak, yang menyenangkan bagi mereka dan gampang untuk ditiru.

\section{Pembiasaan}

Pembiasaan memiliki peran yang sangat penting dalam kehidupan manusia ia mengambil porsi yang sangat besar dalam usaha manusia bahkan dalam ajaran islam menggunakan kebiasaan sebagai salah satu sarana pendidikan. Ahmad Amin dalam Humaidi Tatapangarsa (1973), membuat definisi bahwa yang disebut akhlak itu atau karakter ialah “Adatul Irodah” artinya kehendak yang dibiasakan. Kebiasaan itu ialah perbuatan yang diulang sehingga mudah melakukannya.

Karakter pada dasarnya disusun dari kebiasaan -kebiasaan kita karena bersifat konsisten, sering berpola yang tidak disadari, kebiasaan itu secara konstan, setiap hari mengungkapkan karakter kita. Hal ini sesuai dengan definisi akhlak yaitu, kehendak jiwa manusia yang menimbulkan perbuatan dengan mudah karena kebiasaan, tanpa memerlukan pertimbangan pikiran lebih dahulu (Humaidi Tata Pangersa 1973).

Ibnu Maskawih (1998) dalam Aswandi (2010), mengatakan bahwa "karakter manusia terletak pada pikirannya dan dapat dicapai melalui pendidikan dan pengamalan, pengulangan atau kebiasaan dan disiplin”.

Anak usia dini berada pada tahapan heteromonous (usia 2-6 tahun) menurut Piaget, memiliki karakter yaitu: anak masih sangat labil, mudah terbawa arus, mudah terpengaruh, dan dalam rangka pendidikan moral mereka sangat membutuhkan bimbingan, proses latihan serta pembiasaan yang terus menurut. Sesuai dengan pendapat dari pusat pengembangan dan pendidikan anak usia dini (Early Childhood Education and Development Center, 2003) dalam Otib Satibi (2004) yang menyatakan bahwa anak membutuhkan latihan dan rutinitas. 
Melakukan sesuatu secara berulang-ulang adalah suatu keharusan dan kesenangan bagi anak usia dini.

Upaya penanaman dan pengembangan perilaku moral yang akan menjadi karakter anak yang dilakukan orang tua maupun guru di sekolah, tidak dapat dipisahkan dari proses sosialisasi yang terjadi antara mereka. Moralitas anak usia dini dan perkembangannya dalam tatanan kehidupan dunia mereka yaitu seperti :

a. Sikap dan cara berhubungan dengan orang lain (sosialisasi),

b. Cara berpakaian dan berpenampilan,

c. Sikap dan kebiasaan makan,

d. Sikap dan perilaku anak yang memperlancar hubungannya dengan orang lain.

\section{Contoh atau Teladan}

Abdullah Nashih Alwan (1999) dalam bukunya “tarbiyatul Aulad “ mengatakan”keteladanan dalam pendidikan merupakan metode yang berpengaruh dan terbukti paling berhasil atau membekas dalam mempersiapkan dan membentuk aspek karakter, moral, spiritual dan etos sosial anak”Aswandi,(2010).

Keteladanan adalah alat utama dalam pendidikan. Hal ini dipraktikkan oleh Rasulullah SAW dalam mendidik umatnya. “ Sungguh telah ada pada diri Rosulullah saw contoh teladan yang baik (QS.Al- Ahzab : 21)

Dalam pandangan ilmu psikologi anak usia dini memiliki keunikan, karakter khusus, dan kemampuan meniru yang luar biasa serta rasa ingin tahu yang tinggi, dalam pengembangan perilaku memerlukan pembiasaan yang terus menerus.. Oleh sebab itu orang tua dan guru harus memberi contoh dan teladan yang baik sebab akan ditiru oleh anak. Ruang lingkupnya dimulai dari kebutuhan anak tentang rutinitas kehidupan pribadi anak mulai dari mereka bangun tidur sampai tidur kembali.

Dikatakan bahwa anak melihat orang tua atau gurunya berdusta, ia tak mungkin belajar jujur. Melihat orang tua atau gurunya berkhianat ia tak mungkin belajar amanah, dsb. 


\section{Pembelajaran secara Terintegrasi}

Strategi pengembangan karakter anak usia dini melalui tiga kegiatan yakni kegiatan rutinitas, kegiatan terintegrasi dan kegiatan khusus. Kegiatan rutinitas adalah kegiatan sehari-hari yang dilaksanakan secara terus menerus namun terprogram dengan pasti. Seperti membaca salam, membaca doa masuk kelas,berdoa sebelum dan sesudah belajar, doa sebelum dan sesudah makan dan kebiasaan rutin lainnya. Kegiatan terintegrasi adalah kegiatan pengembangan karakter disisipkan melalui pengembangan bidang kemampuan dasar lainnya. Program ini harus tercantum secara jelas berikut langkah-langkah dan kompetensi dasarnya dalam satuan kegiatan harian (SKH) yang disusun oleh guru. Pendidikan dan pembelajaran berbasis karakter, berbasis nilai, berbasis moral dan sejenisnya dirancang dan dilaksanakan secara terintegrasi dan pembelajaran dan pengembangan lainnya.

\section{Mengembangkan Sikap dan Perilaku Anak Usia Dini}

Dalam mengembangkan sikap dan perilaku anak usia dini dalam pendidikan karakter mengacu kepada acuan yang telah ditetapkan Kemendiknas dalam grand design pendidikan karakter bangsa, telah ditetapkan pengelompokan konfigurasi karakter, yakni olah hati,olah rasa-karsa, olah pikir, dan olah raga yang perlu dikembangkan dalam sikap dan perilaku anak usia dini. Adapun nilainilai yang termasuk olah hati: Keimanan-ketaqwaan, kejujuran, tanggung jawab, memiliki rasa keadilan, berbakti pada orang tua, memiliki jiwa rela berkurban, dan berani menghadapi risiko. Olah Rasa-Karsa: Memiliki rasa peduli dan empati, santun dan ramah, budaya rapi, memiliki jiwa nasionalisme, cinta tanah air, pola pikir yang dinamis, dan etos kerja. Adapun yang termasuk olah pikir: memilki kecerdasan, memiliki sikap kritis, memiliki jiwa kreatif, inovatif, berpikir terbuka, memiliki sikap optimis dan produktif. Olah raga meliputi: memiliki jiwa tangguh dan berdaya tahan, menjaga kebersihan dan kesehatan, membiasakan disiplin dalam segala hal, memiliki jiwa sportif, menyukai kerja sama dan persahabatan, dan menampakkan sikap gigih. 


\section{E. Kesimpulan}

1. Pendidikan karakter adalah pendidikan untuk membentuk kepribadian seseorang melalui pendidikan budi pekerti yang hasilnya terlihat dalam tindakan nyata seseorang, yaitu tingkah laku yang baik, jujur, bertanggung jawab, menghormati hak orang lain, dsb. Karakter disebut juga perangai, watak atau tabiat.

2. Pengembangan karakter pada anak usia dini dilakukan dengan cara:
a. Memberi pemahaman yang benar tentang pendidikan karakter
b. Melalui pembiasaan
c. Melalui contoh dan teladan
d. Pembelajaran secara terintegrasi

3. Acuan Pengembangan sikap dan karakter bagi anak usia dini adalah mengacu kepada ketetapan Kemendiknas adalah pengelompokan konfigurasi karakter yakni: Olah hati, olah pikir, olah rasa-karsa dan olah raga.

\section{DAFTAR PUSTAKA}

Al Quran Dan Terjemahnya, Departemen Agama R.I.

Asmaran AS. (2002), Pengantar Studi Akhlak, Raja Grafindo Persada, Jakarta

Aswandi, (2011), Pendidikan Karakter (Jurnal Publikasi Ilmiah PU UPI) Asosiasi Arjana dan Dosen PU, Bandung

Bambang Q Anis, Adang Hambali, (2008) Pendidikan Karakter Berbasis AlQuran, Simbiosa Rekatama Media, Bandung

Budiningsih C. Asri (2004), Pembelajaran Moral, Rineka Cipta, Jakarta

Koesoema, Doni A, (2007), Tiga Matra Pendidikan Karakter, Basis

Satibi Otib,(2004), Metode Pengembangan Moral dan Nilai-nilai agama, Jakarta

Tafsir A. (2008), Pesan Moral Ajaran Islam, Maestro, Bandung

Tata Pangarsa H. (1979), Pengantar Kuliah Akhlak, Bina Ilmu, Surabaya

Zainudin Din, (2004), Pendidikan Budi Pekerti dalam Perspektif Islam, Almawardi Prima, Jakarta 


\section{BIODATA PENULIS}

Edi Rohendi adalah dosen pada Universitas Pendidikan Indonesia dpk. UPI Kampus Cibiru Bandung. Penulis menyelesaikan pendidikan jenjang magister (S-2) pada Program Studi Pendidikan Umum/Nilai dari Sekolah Pascasarjana Universitas Pendidikan Indonesia. 